INFINITY-Jurnal Matematika dan Aplikasinya (IJMA)

Volume 1 | Nomor 2 | Maret|2021

\title{
Penerapan Model Pembelajaran Berbasis Masalah untuk Meningkatkan Penalaran Kuantitatif Siswa SMP
}

\section{Muhammad Muzaini ${ }^{1}$}

Corespondensi Author
'UFakultas Keguruan dan Ilmu Pendidikan
Universitas Cokroaminoto Palopo,
Palopo, Indonesia

'[Email:muhammadmuzaini@uncp.ac.id]

Kata Kunci:

Penalaran Kuantitatif, Pembelajaran

Berbasis Masalah, SMP I Pangkajene.
Abstrak. Kemampuan siswa sekolah
menengah pertama untuk bernalar secara
kuantitatif dalam konteks pembelajaran
matematika diselidiki dengan menggunakan
alat Ukur tes penalaran kuantitatif dan lembar
observasi, yang akan dikembangkan.
Penelitian ini didesain dengan trueexperimental design by the randomized pretest - post-test control group design. Partisipan dari penelitian ini dari Sekolah Menengah 1 Pangkajene yang terdiri dari 2 kelas (kelas eksperimen dan kelas kontrol, (50) di kelas eksperimen, (45) di kelas kontrol, dengan jumlah total 95 peserta didik). Model pembelajaran berbasis masalah diimplementasikan pada kelas eksperimen sedangkan kelas kontrol diterapkan pada kurikulum saat ini. Hasil penelitian kelas eksperimen yang dilakukan, berdasarkan analisis data ditemukan bahwa data tes penalaran kuantitatif dan lembar observasi siswa kelas eksperimen lebih baik daripada siswa kelas kontrol. Selanjutnya, berdasarkan hasil tes penalaran kuantitatif, $86,1 \%$ siswa memperoleh $\mathrm{N}-$ Gain lebih dari atau sama dengan 0,7. Oleh karena itu, dimungkinkan untuk mengatakan bahwa model pembelajaran berbasis masalah lebih efisien daripada pembelajaran di kelas kontrol. Sehingga tes penalaran kuantitatif dan lembar observasi dapat direkomendasikan untuk studi selanjutnya.

\section{PENDAHULUAN}

Penalaran adalah proses berpikir dalam proses menyimpulkan (Sumarmo, 2013). Penalaran menurut Gorys (2007) bahwa proses berpikir yang berupaya menghubungkan fakta yang diketahui mengarah pada kesimpulan. Secara garis besar, penalaran dibagi menjadi dua yaitu induktif dan deduktif. Membuat kesimpulan berdasarkan beberapa kasus atau contoh disebut induksi sedangkan membuat kesimpulan berdasarkan aturan yang disepakati disebut deduksi (Sumarmo, 1987). Penalaran adalah salah satu aspek dari tujuan matematika sekolah menengah. Hal ini terbukti dalam Peraturan Menteri Pendidikan Nasional No. 22 tahun 2006 (Kementerian Pendidikan dan Kebudayaan, 2006) yang menyatakan bahwa matematika sekolah menengah bertujuan untuk 
membuat siswa memiliki kemampuan untuk menggunakan penalaran pada pola dan sifat, membuat manipulasi matematika dalam membuat generalisasi, mengumpulkan bukti atau menjelaskan ide dan pernyataan matematika, menyelesaikan masalah yang mencakup kemampuan untuk memahami masalah, merancang model matematika, melengkapi model dan menafsirkan solusi yang diperoleh. Penjelasan tersebut menyatakan bahwa tujuan pengajaran matematika di sekolah menengah adalah untuk mengembangkan kemampuan menggunakan penalaran. Sehingga Matematika berperan penting dalam melatih siswa beralasan dalam menyimpulkan untuk menyelesaikan masalah, baik masalah matematika maupun masalah dalam kehidupan sehari-hari.

Penalaran kuantitatif adalah salah satu proses mental penting bagi siswa dalam matematika (Thompson, 1993; Ellis, 2007a; Ellis, 2007b; Ellis, 2011; Carlson \& Oehrtman, 2013; Hackenberg, 2010a; Hackenberg, 2010b; Moore, 2014; Weber et al. 2014; Ramful \& Ho, 2015). Penalaran Kuantitatif adalah kemampuan yang dikembangkan dalam pembelajaran matematika untuk menganalisis informasi kuantitatif dan untuk menentukan keterampilan dan prosedur yang dapat diterapkan pada masalah tertentu untuk sampai pada suatu solusi. Tujuan pendidikan matematika termasuk mendiskusikan penalaran kuantitatif sebagai kemampuan yang harus dikembangkan di semua siswa (NCTM, 2000; MAA, 2003; Howe, 1998; AMATYC, 1995). Sroyer (2013) mendefinisikan penalaran kuantitatif sebagai alasan yang menekankan pada penarikan kesimpulan berdasarkan data atau informasi kuantitatif. Selanjutnya, Dweyer et al. (2003) menyatakan bahwa penalaran kuantitatif perlu dikembangkan dalam pembelajaran matematika untuk mengembangkan kemampuan siswa untuk menganalisis informasi kuantitatif dan menentukan keterampilan dan prosedur yang dapat diterapkan pada masalah tertentu untuk sampai pada solusi atau kesimpulan. Carroll (1993) menyatakan bahwa penalaran kuantitatif sudah ada pada anak usia lima tahun hingga dewasa. Dia menyimpulkan bahwa ada tiga kemampuan penalaran utama: berurutan (deduktif), induktif, dan kuantitatif. Ada 4 jenis pertanyaan untuk mengukur QR, yaitu: perbandingan kuantitatif, pilihan ganda (pilihan ganda pilihan), pilihan ganda (pilihan ganda pilihan satu atau lebih), dan masukkan jawaban dalam kotak (entri numerik) (ETS, 2010).

Hasil penelitian menyatakan secara positif bahwa penalaran kuantitatif memiliki efek yang baik pada siswa karena akan dapat membuat siswa memahami dan membuat argumen yang baik didukung oleh fakta-fakta kuantitatif dan dapat mengkomunikasikan argumen ini dengan jelas dalam berbagai representasi (Madison, 2003 \& Kabael et al , 2016). Terungkap bahwa penggunaan penalaran kuantitatif akan meningkatkan tingkat kemampuan siswa untuk memahami dan memecahkan masalah dalam kehidupan seharihari, jumlah alasan atau tingkat penguasaan angka, perhitungan mental akan lebih baik atau perhitungan tanpa menggunakan alat tetapi menggunakan otak tetapi menggunakan otak, dan dapat menilai solusi dari suatu masalah (Karim, 2007). Selanjutnya, penalaran kuantitatif memiliki nilai yang sangat penting dalam pembelajaran matematika di sekolah (Madison, 2003 \& Kabael et al. 2016). Hasil penelitian terbaru menekankan bahwa guru matematika memiliki peran penting dalam mengembangkan penalaran kuantitatif siswa (Kabael et al, 2016). Ellis (2007) menyatakan bahwa untuk meningkatkan penalaran kuantitatif siswa dalam lingkungan belajar sangat tergantung pada guru matematika yang dapat menggunakan pertanyaan yang terstruktur dengan baik, seperti mengajukan pertanyaan yang tepat, mengarahkan siswa untuk mempertimbangkan dengan cermat hubungan kuantitatif dihadapkan dalam situasi masalah dan berpikir secara kuantitatif.

Berdasarkan uraian di atas, pembelajaran dapat diterapkan untuk meningkatkan 
penalaran kuantitatif siswa, yaitu Problem Based Learning (PBL). Pembelajaran Berbasis Masalah adalah tepat dan sesuai untuk siswa karena menggunakan masalah kontekstual sebagai titik awal untuk belajar dengan pertanyaan yang terstruktur dengan baik, seperti mengajukan pertanyaan yang tepat, mengarahkan siswa untuk mempertimbangkan dengan cermat hubungan kuantitatif dalam situasi masalah dan berpikir secara kuantitatif. Dampaknya adalah meningkatkan tingkat kemampuan siswa untuk memahami dan memecahkan masalah dalam kehidupan sehari-hari.

\section{Pembelajaran Berbasis Masalah}

Problem Based Learning (PBL) adalah salah satu model pembelajaran yang menggunakan masalah kontekstual sebagai konteks bagi siswa untuk belajar tentang penalaran pemecahan masalah (Arends, 2012). Pemilihan model PBL juga mengikuti tujuan pembelajaran matematika yang berfokus pada cara berpikir atau bernalar, mengembangkan kegiatan kreatif, mengembangkan keterampilan pemecahan masalah, dan mengkomunikasikan ide. Problem Based Learning (PBL) adalah salah satu pendekatan yang berpusat pada siswa dan telah dipertimbangkan oleh beberapa lembaga pendidikan tinggi di banyak bagian dunia sebagai metode pengiriman (Awang \& Ramly, 2008). Model Pembelajaran Berbasis Masalah mengubah siswa dari penerima informasi pasif menjadi pembelajar mandiri, aktif, dan penyelesaian masalah, dan itu menggeser penekanan program pendidikan dari mengajar ke pembelajaran (Akınoğlu \& Tandoğan, 2007). Pembelajaran PBL mengharuskan siswa untuk mengajukan pertanyaan dan mengungkapkan pendapat, menemukan informasi yang relevan dari sumber tersembunyi untuk menemukan berbagai cara (alternatif) untuk mendapatkan solusi dan menemukan cara yang paling efektif untuk menyelesaikan masalah. Berdasarkan sintaksis Problem Based Learning (PBL), model belajar mengajar ini menuntut siswa untuk lebih aktif dalam penalaran dalam menyelesaikan masalah. Pembelajaran Berbasis Masalah yang melibatkan siswa dalam penyelidikan mereka, memungkinkan siswa untuk menafsirkan dan menjelaskan fenomena dunia nyata dan membangun pemahaman mereka tentang fenomena ini. Berikut ini di bawah sintaks Pembelajaran Berbasis Masalah (Arends, 2012).

Tabel 1. Fase Pembelajaran Berbasis Masalah (PBL)

\begin{tabular}{|c|c|}
\hline Fase & Teacher Actvities \\
\hline $\begin{array}{l}\text { Fase } 1 \\
\text { Student orientation to } \\
\text { problems }\end{array}$ & $\begin{array}{l}\text { - } \\
\text { - } \\
\text { - } \\
\text { - } \\
\text { Motiviainain the studentents to be actively involved in solving } \\
\text { selected problems }\end{array}$ \\
\hline $\begin{array}{l}\text { Fase } 2 \\
\text { Organizing students }\end{array}$ & $\begin{array}{l}\text { - Helps students define and organize learning tasks relat } \\
\text { to problems }\end{array}$ \\
\hline $\begin{array}{l}\text { Fase } 3 \\
\text { Individual and group } \\
\text { research guides }\end{array}$ & $\begin{array}{l}\text { - Encourage students to gather information accordingly } \\
\text { - Encourage students to conduct experiments for } \\
\text { explanation and problem solving }\end{array}$ \\
\hline $\begin{array}{l}\text { Fase } 4 \\
\text { Develop and present } \\
\text { work results }\end{array}$ & $\begin{array}{l}\text { - Assist students in planning and preparing appropriate } \\
\text { work results such as reports, models, and sharing } \\
\text { assignments with friends. }\end{array}$ \\
\hline
\end{tabular}


Phase 5

Analyze and evaluate the process problem solving
- Evaluate learning outcomes about the material that has been learned / request group presentations from student work.

Penelitian ini bertujuan untuk menyelidiki cara bernalar secara kuantitatif dalam konteks pembelajaran matematika untuk siswa sekolah menengah, pertanyaanpertanyaan di bawah ini yang perlu dijawab.

1. Apakah ada perbedaan yang signifikan antara (nilai pre-test dan post-test) yang menunjukkan kemampuan penalaran kuantitatif dari kelas eksperimen dan kelas kontrol?

2. Apakah ada peningkatan antara skor siswa (pre-test dan post-test) yang menunjukkan kemampuan penalaran kuantitatif dari kelas eksperimen dan kelas kontrol?

\section{METODE}

Penelitian ini menggunakan penelitian true-experimental dengan control grup desaing pre-test - post-test . Populasi penelitian adalah semua 8 siswa kelas Sekolah Menengah 1 Pangkajene. Sampel penelitian ini terdiri dari 8,1 kelas dan 8,2 kelas dari populasi sampel 8 kelas dengan total 95 siswa. Kelas eksperimen yang diajarkan dengan pembelajaran berbasis masalah adalah 8,1 kelas yang terdiri dari 28 siswa perempuan dan 22 siswa laki-laki, sedangkan kelas kontrol yang diajarkan dengan diterapkan pada kurikulum saat ini adalah 8,2 kelas yang terdiri dari 25 siswa perempuan dan 20 siswa laki-laki.

Instrument pengumpulan data yang dikembangkan dalam penelitian ini menggunakan lembar tes kemampuan penalaran kuantitatif (TKPK) dan lembar observasi. Instrumen tes TKPK terdiri dari 5 pertanyaan tentang topik program linier. Lembar observasi terdiri dari mengamati kegiatan guru dan kegiatan siswa untuk melihat kegiatan siswa selama pelajaran. Sebelum melakukan penelitian, instrumen tes TKPK dan lembar observasi divalidasi oleh para ahli yang terdiri dari 3 dosen dan 1 guru matematika. setelah dinyatakan valid dengan koefisien validitas 0,85 dan koefisien reliabilitas 0,74 .

Selanjutnya, item tes deskripsi TKPK diuji kepada siswa untuk mendapatkan tingkat validitas dan tingkat reliabilitas instrumen yang akan digunakan, item TKPK diuji di luar subjek penelitian. Untuk mengukur validitas suatu item, Anda dapat menggunakan rumus korelasi momen-produk (Arikunto, 2012 \& Malhotra et al. 2007) di bawah:

\section{Rumus Product-Moment}

$\mathrm{r}_{\mathrm{xy}}=\frac{n \sum_{i=1}^{n} x_{i j} y_{i}-\left(\sum_{i=1}^{n} x_{i j} \sum_{i=1}^{n} y_{i}\right)}{\sqrt{\left\{n \sum_{i=1}^{n} x_{i j}^{2}-\left(\sum_{i=1}^{n} x_{i j}\right)^{2}\right\} \cdot\left\{n \sum_{i=1}^{n} y_{i}^{2}-\left(\sum_{i=1}^{n} y_{i}\right)^{2}\right\}}}$

Selanjutnya, untuk menghitung koefisien reliabilitas item tes Alpha-Cronbach (Urbina, 2004) digunakan sebagai berikut:

The reliability coefficient the Alpha-Cronbach test

$\mathrm{r}_{11}=\left(\frac{n}{n-1}\right)\left(1-\frac{\sum_{i=1}^{n} \sigma_{i}^{2}}{\sigma_{t}^{2}}\right)$

Analisis Data hasil pre-tes TKPK dibandingkan dengan uji Mann-Whitney U nonparametrik. Sebagai hasil perbandingan, tidak ada perbedaan yang signifikan antara skor 
kelompok eksperimen dan kontrol dalam hal skor pra-tes TKPK. Karena skor post-tes TKPK dari kelompok eksperimen dan kontrol memberikan proposisi pengujian parametrik, mereka dibandingkan dengan uji-t independen.

Table 2. Mann-Whitney U test results of TKPK pre-test scores

\begin{tabular}{lllllll}
\hline Test & Group & N & Averag & Total & U & P \\
\hline \multirow{4}{*}{ TKPK } & \multirow{2}{*}{ Experimental } & 5 & \multirow{2}{*}{55.53} & 2776.5 & 472.0 & \\
& & 0 & & 2304.4 & 5 & \\
& Control & 4 & \multirow{2}{*}{51.21} & 5 & & \\
\hline
\end{tabular}

Kriteria hipotesis: hipotesis $\left(\mathrm{H}_{0}\right)$ diterima jika: Thitung $>$ Ttabel dan hipotesis $\left(\mathrm{H}_{1}\right)$ ditolak. Hipotesis penelitian adalah sebagai berikut:

- $\mathrm{H}_{0}$ : Apakah ada perbedaan yang signifikan antara (nilai pre-test dan post-test) yang menunjukkan kemampuan penalaran kuantitatif dari kelas eksperimen dan kelas kontrol?

- $\mathrm{H}_{1}$ : Apakah ada peningkatan antara skor siswa (pre-test dan post-test) yang menunjukkan kemampuan penalaran kuantitatif dari kelas eksperimen dan kelas kontrol?

Selanjutnya, untuk menentukan peningkatan dalam hasil pretest (TKPK) dan posttest (TKPK), hasil perhitungan di atas selanjutnya dikategorikan dan dicocokkan dengan interpretasi berdasarkan formula dan kriteria pada Tabel 3 (Nani \& Kusumah, 2015; Hasbi et al. 2019).

The N-Gain Formula

$$
\mathrm{N}-\text { Gain }=\frac{\text { Posttest Score }- \text { Pretest Score }}{\text { Maksimum Score-Pretest Score }}
$$

Table 3. N-Gain Value Criteria

\begin{tabular}{lc}
\hline \multicolumn{1}{c}{$\mathrm{N}$-Gain } & Criteria \\
\hline $\mathrm{N}$-Gain $\geq 0,70$ & High \\
$0,30 \leq \mathrm{N}-$ Gain $<0,70$ & Medium \\
$\mathrm{N}-$ Gain $\leq 0,30$ & Low \\
\hline
\end{tabular}

Nilai N-Gain rata-rata yang diperoleh siswa di kelas eksperimen adalah 86,1\% lebih dari atau sama dengan 0,7. Sementara di kelas kontrol yang 65\% lebih dari atau sama dengan 0,3 ..

Table 4. $N$-Gain results of TKPK post-test

\begin{tabular}{cc}
\hline N-Gain & Criteria \\
\hline N-Gain $\geq 0,70$ & $86.1 \%$ \\
$0,30 \leq$ N-Gain $<0,70$ & $65 \%$ \\
\hline
\end{tabular}

\section{HASIL DAN PEMBAHASAN}

Proses penelitian dimulai dengan memberikan tes TKPK ke kedua kelas untuk melihat tingkat kemampuan penalaran kuantitatif awal siswa. Setelah menerapkan pembelajaran berbasis masalah, tes diberikan untuk melihat peningkatan kemampuan penalaran kuantitatif siswa. Kelas kontrol dan kelas eksperimen diberi perlakuan 
pembelajaran yang berbeda. Tabel 5 menunjukkan hasil TKPK untuk mengungkapkan jika pengajaran yang dirancang menciptakan perbedaan yang signifikan dalam penalaran kuantitatif siswa dalam hal nilai pre-test dan post-test.

Table 5. Results of TKPK scores

\begin{tabular}{llccc}
\hline \multirow{1}{*}{ Test } & \multicolumn{1}{c}{ Class } & $\begin{array}{c}\text { Number of } \\
\text { Subject }\end{array}$ & $\begin{array}{c}\text { Highest } \\
\text { Score }\end{array}$ & Lowest Score \\
\cline { 2 - 5 } Pre-Test & Experiment & 50 & 70 & 45 \\
Post- & Control & 45 & 65 & 40 \\
Test & Experiment & 50 & 100 & 75 \\
\hline
\end{tabular}

Tabel 5 di atas, ditemukan bahwa penalaran kuantitatif siswa menggunakan Problem Based Learning (PBL) menunjukkan hasil yang lebih baik dengan melihat ratarata yang diperoleh siswa di kelas eksperimen dan kelas kontrol. Kemudian, analisis awal dilakukan uji normalitas dan homogenitas dengan tujuan untuk mengetahui data dari dua kelompok dengan distribusi normal dan data homogen diperoleh. Selanjutnya, uji hipotesis dilakukan untuk menunjukkan nilai T hitung dari data pre-test dan post-test. Berdasarkan hasil statistik, $\mathrm{T}$ hitung $=15.565$ dan $\mathrm{T}$ table $(\mathrm{N}-2)=1.985$. Sehingga $\mathrm{T}$ hitung $>\mathrm{T}$ table, berdasarkan hipotesis ini (H1) diterima dan (H0) ditolak, sehingga dapat disimpulkan bahwa penalaran kuantitatif siswa menggunakan Problem Based Learning (PBL) pada kelas eksperimen meningkat dan lebih baik daripada siswa yang diberikan dengan pembelajaran konvensional di kelas kontrol. Serta terlihat dari nilai posttest siswa yang memenuhi angka mendapat nilai di atas ketuntasan klasikal. Ketuntasan belajar yang dicapai oleh siswa secara klasikal lebih dari 75\%.

Berdasarkan pengamatan selama pembelajaran di kelas eksperimen, hasilnya menunjukkan bahwa aktivitas guru dalam pembelajaran memenuhi kriteria yang baik pada setiap tahap dalam Problem Based Learning (PBL). Kemudian, kegiatan siswa yang memenuhi kriteria aktif dalam pembelajaran ditandai dengan waktu ideal yang ditetapkan dalam rencana pelajaran untuk memenuhi batas waktu untuk efektivitas toleransi dan memberikan respons positif terhadap pembelajaran matematika di kelas. Siswa belajar awal diberikan masalah kontekstual, sehingga siswa akan memahami informasi kuantitatif dalam masalah; hubungan antara jumlah yang terkandung dalam situasi; mencari hubungan yang sama antara dua atau lebih angka; mencari prosedur untuk mendeteksi hubungan interpersonal; mendeteksi pola dalam situasi tertentu; ulangi pola untuk mendapatkan bentuk umum, dan berlaku untuk situasi baru. Dengan demikian siswa akan membangun pengetahuan mereka dengan menghubungkan pengetahuan sebelumnya dengan pengetahuan mereka saat ini untuk menghasilkan kesimpulan dari materi yang telah diajarkan. Masalah kontekstual difasilitasi oleh guru dalam proses pembelajaran, sehingga siswa antusias karena mereka dapat memecahkan masalah yang berkaitan dengan kehidupan sehari-hari siswa, dan siswa dapat menerapkan keterampilan matematika mereka dalam kehidupan sehari-hari mereka. Juga, masalah yang disajikan mengembangkan kemampuan siswa untuk menganalisis informasi kuantitatif dan menentukan keterampilan dan prosedur yang dapat diterapkan pada masalah tertentu untuk sampai pada solusi atau kesimpulan.

Respon siswa memenuhi kriteria positif untuk pembelajaran yang digunakan karena siswa diberikan masalah kontekstual untuk memahami informasi kuantitatif yang ada dalam masalah; hubungan antara jumlah yang terkandung dalam situasi; mencari 
hubungan yang sama antara dua atau lebih angka; mencari prosedur untuk mendeteksi hubungan antar angka; mendeteksi pola dalam situasi tertentu; ulangi pola untuk mendapatkan bentuk umum, dan berlaku untuk situasi baru. Jadi, siswa termotivasi untuk membangun, menalar, dan mengembangkan keterampilan pengetahuan mereka dengan bimbingan guru yang lebih baik, sehingga penalaran kuantitatif dan pengalaman belajar mereka akan lebih bermakna dan bertahan lama dalam jangka panjang.

Dalam kegiatan pembelajaran, pengamat mengamati aktivitas guru dan aktivitas siswa dalam pembelajaran menggunakan Problem Based Learning (PBL). Berdasarkan pengamatan yang dilakukan oleh pengamat, berikut ini adalah deskripsi proses pembelajaran yang diperoleh. Tahap perlakuan atau implementasi pembelajaran dilakukan dengan beberapa pertemuan. Setiap pertemuan berlangsung 90 menit dengan perkiraan waktu belajar dari kegiatan awal hingga penutupan. Materi yang dibahas dalam setiap pertemuan dalam penelitian ini adalah materi program linier. Untuk setiap pertemuan, siswa diberikan masalah kontekstual terkait dengan materi program linier, dalam hal ini, luas permukaan dan volume program linier yang akan dibahas dengan teman-teman kelompok siswa. Kegiatan belajar awal, guru mengatur kelas untuk kegiatan belajar dan menyampaikan tujuan materi yang akan dipelajari. Guru membentuk kelompok berdasarkan jenis kelamin dan tingkat kemampuan siswa dengan tujuan bahwa siswa akan mengadakan diskusi kelompok dan memecahkan masalah yang telah disampaikan oleh guru.

Ketika diskusi materi berlangsung, beberapa siswa di setiap kelompok mengajukan pertanyaan kepada guru tentang masalah kontekstual yang mereka diskusikan. Dalam proses pembelajaran, guru tidak langsung menjawab pertanyaan dari siswa, tetapi guru hanya mengulangi materi dan memberikan bimbingan yang masuk akal, sehingga siswa dapat menemukan jawaban mereka. Juga, guru memotivasi siswa untuk mengeksplorasi dan membangun keterampilan matematika, sehingga siswa yang terlibat dalam kegiatan belajar memahami matematika secara umum. Setelah diskusi kelompok selesai, guru meminta satu perwakilan dari setiap kelompok untuk mempresentasikan hasil diskusi mereka dan menuliskannya di papan tulis. Setelah kelompok mempresentasikan dan mempresentasikan hasil diskusi, guru memeriksa apakah hasilnya mengikuti apa yang diharapkan dalam tujuan pembelajaran. Kemudian guru akan menjelaskan lebih lanjut untuk mengkonfirmasi hasil diskusi dari masing-masing kelompok. Di akhir pelajaran, guru dan siswa menganalisis dan mengevaluasi proses pemecahan masalah.

Penelitian ini dilakukan oleh beberapa peneliti sebelum menggunakan Problem Based Learning (PBL). Secara umum, hasil penelitian ini dapat meningkatkan penalaran kuantitatif siswa. Penelitian ini menunjukkan bahwa penalaran kuantitatif rata-rata siswa yang menggunakan Problem Based Learning (PBL) meningkat dan lebih baik daripada kelas kontrol. Hasil ini terjadi karena proses pembelajaran menggunakan Problem Based Learning (PBL) mendorong dan memotivasi siswa untuk menemukan jawaban mereka terhadap masalah yang diberikan. Dengan menggunakan Problem Based Learning (PBL) yang terhubung dengan konsep matematika itu sendiri, konsep ilmiah lainnya dan kehidupan sehari-hari lainnya, siswa dapat mengembangkan kemampuan siswa untuk menganalisis informasi kuantitatif dan menentukan keterampilan dan prosedur yang dapat diterapkan pada masalah tertentu untuk sampai pada solusi atau kesimpulan (Dweyer et al. 2003).

Teori belajar adalah panduan bagi guru untuk membantu siswa mengembangkan kognitif, sosial, dan spiritual mereka. Perkembangan sejauh ini dengan Pembelajaran Berbasis selalu didasarkan pada 4 teori yaitu teori Piaget, teori Vygotsky, teori Bruner, dan teori Ausubel (Slavin, 2006). Dengan belajar teori, belajar dan berpikir mengubah 
dan mengembangkan struktur kognitif. Dalam teorinya, Piaget berpendapat bahwa struktur kognitif seseorang terjadi karena proses adaptasi. Adaptasi adalah proses menyesuaikan skema dalam menanggapi lingkungan melalui dua proses asimilasi dan akomodasi.

Proses pembelajaran dengan PBL sangat erat kaitannya dengan teori, hal ini didasarkan pada teori Piaget, karena Problem Based Learning (PBL) berfokus pada bagaimana siswa berpikir dan bernalar, tidak fokus pada hasil pencapaian siswa. Selanjutnya, siswa yang diberi masalah kontekstual akan diizinkan untuk mendefinisikan dan mengatur tugas belajar yang terkait dengan masalah, Siswa mengumpulkan informasi kuantitatif sesuai, siswa untuk melakukan eksperimen untuk penjelasan dan pemecahan masalah (Arends, 2012). Salah satu teori penting dalam psikologi perkembangan siswa dalam teori Vygotsky. Teori ini menekankan sifat pembelajaran sosiokultural. Di bawah pendapat Vygotsky bahwa pembelajaran terjadi ketika anakanak bekerja atau belajar dalam menyelesaikan tugas-tugas yang belum dipelajari sebelumnya tetapi tugas-tugas ini masih dalam zona perkembangan proksimal. Secara universal, fungsi mental yang lebih tinggi muncul dalam percakapan atau kerja sama antara individu, sebelum fungsi mental yang lebih tinggi diserap ke dalam individu menurut Vygotsky (Slavin, 2006). Ini berisi dua efek utama berdasarkan teori Vygotsky tentang belajar sains. Pertama, kondisi di kelas dirancang dengan pembelajaran kooperatif, sehingga dengan kelompok-kelompok ini siswa akan dapat berinteraksi dengan teman-teman kelompok untuk memecahkan masalah yang diklasifikasikan sebagai sulit dan menghasilkan strategi pemecahan masalah yang efektif di setiap zona pengembangan proksimal mereka. Kedua, teori ini juga berlaku untuk mereka yang mengajar dengan menekankan memberikan bantuan atau bimbingan sehingga siswa menjadi semakin bertanggung jawab untuk pembelajaran mereka (Slavin, 2006). Teori ini mengikuti Problem Based Learning (PBL), yang merupakan masalah kontekstual yang disajikan kepada siswa dalam memahami dan menyelesaikannya dirancang dalam kelompok, dan siswa dalam merencanakan dan menyiapkan hasil kerja yang sesuai seperti laporan, model, dan berbagi tugas dengan teman-teman . Dengan model ini, setiap siswa akan merasa percaya diri dan bertanggung jawab atas pengetahuan mereka yang diperoleh dari hasil diskusi dan dapat meningkatkan penalaran kuantitatif siswa.

Belajar matematika adalah belajar tentang konsep dan struktur matematika yang ditemukan dalam materi yang sedang dipelajari dan untuk menemukan hubungan antara konsep Bruner dan struktur matematika (Hudoyo, 1988). Melalui konsep dan struktur ini, sehingga materi akan dipahami secara komprehensif. Selain itu, pengetahuan siswa lebih mudah diingat, dan bertahan lebih lama jika materi yang dipelajari memiliki pola terstruktur. Selanjutnya, dalam teori ini perkembangan kognitif siswa dikembangkan melalui tiga tahap, yaitu tahap aktif di mana siswa belajar untuk menggunakan objek beton secara langsung sehingga mereka dapat memanipulasi objek beton, tahap ikonik yang tidak menggunakan benda konkret tetapi menggunakan benda konkret, simbolik. tahap di mana siswa belajar dengan memanipulasi simbol secara langsung yang tidak terkait dengan objek. Jadi, dapat disimpulkan bahwa teori Bruner mengikuti pembelajaran berbasis masalah, kesesuaian orientasi siswa dengan masalah, dan kesesuaian pengorganisasian siswa, kesesuaian dengan pedoman penelitian individu dan kelompok, ketiga adalah untuk mengembangkan dan mempresentasikan hasil kerja, dan kesesuaian dalam menganalisis dan mengevaluasi proses penyelesaian masalah. 


\section{KESIMPULAN}

Berdasarkan hasil analisis data di atas diperoleh dari pre-test, post-test, dan observasi di kelas eksperimen dan kelas kontrol. Kesimpulan dalam penelitian ini dilakukan di Sekolah Menengah 1 Pangkajene disajikan di bawah ini:

a) Kemampuan penalaran kuantitatif siswa dalam pembelajaran matematika untuk menggunakan pembelajaran berbasis masalah (PBL) dalam perbedaan kelas eksperimen secara signifikan dan lebih baik daripada kelas kontrol.

b) Kemampuan penalaran kuantitatif siswa untuk menggunakan pembelajaran berbasis masalah (PBL) di kelas eksperimen meningkat secara signifikan dan lebih baik daripada kelas kontrol.

c) Pengamatan, kegiatan guru dilakukan dengan baik dan kegiatan siswa menunjukkan bahwa mereka secara aktif ditandai oleh siswa yang lebih antusias dalam belajar matematika menggunakan pembelajaran berbasis masalah (PBL).

d) Berdasarkan hasil tes penalaran kuantitatif siswa, 86,1\% siswa memperoleh Ngain lebih dari atau sama dengan 0,7. Oleh karena itu, dimungkinkan untuk mengatakan bahwa pembelajaran berbasis masalah lebih efisien daripada pembelajaran di kelas kontrol.

Kesimpulan yang diperoleh di atas adalah bahwa pembelajaran matematika menggunakan Problem Based Learning (PBL) dapat meningkatkan penalaran kuantitatif siswa dan guru harus menguasai model pembelajaran seperti Problem Based Learning (PBL) sehingga proses pembelajaran di kelas menjadi lebih aktif, beragam, dan belajar akan bermakna sehingga pengetahuan siswa akan bertahan lama dan akan meningkatkan hasil belajar siswa (Penalaran Kuantitatif) menjadi lebih baik. 


\section{REFERENSI}

Akınoğlu, O., \& Tandoğan, R. O. (2007). The Effects of Problem-Based Active Learning in Science Education on Students' Academic Achievement, Attitude and Concept Learning. Eurasia Journal of Mathematics, Science \& Technology Education, 3(1), 7181.f

American Mathematical Association of Two-Years Colleges. (1995). Crossroads in Mathematics: Standards For İntroductory College Mathematics Before Calculus.

Arends, R. I. (2012). Learning to Teach ninth edition. New York: McGraw-Hill.

Arikunto, S. (2013). Fundamentals of Educational Evaluation. Jakarta: PT. Earth Literacy.

Awang, H., \& Ramly, I. (2008). Creative Thinking Skill Approach Through Problem-Based Learning: Pedagogy and Practice in the Engineering Classroom. International Journal of Human and Social Sciences 3:1.

Carroll, J. B. (1993). Human Cognitive Abilities: A Survey of Factor-Analytic Studies. Cambridge, England: Cambridge University Press.

Carlson, M. P., Oehrtman, M., \& Moore, K. (2013). Precalculus Pathways To Calculus Student Workbook.

Dwyer, C. A., Gallagher, A., Levin, J., \& Morley, M. E. (2003). What İs Quantitative Reasoning? Defining The Construct For Assessment Purposes. ETS Research Report Series, 2003(2), i-48.

Ellis, A. B. (2007). A taxonomy for categorizing generalizations: Generalizing actions and reflection generalizations. The Journal of the Learning Sciences, 16(2), 221-262.

Ellis, A. B. (2007). Connections Between Generalizing And Justifying: Students' Reasoning With Linear Relationships. Journal for Research in Mathematics Education, 194-229.

Ellis, A. B. (2011). Algebra İn The Middle School: Developing Functional Relationships Through Quantitative Reasoning. In Early algebraization (pp. 215-238). Springer, Berlin, Heidelberg.

Gorys, K. (2007). Argumentation and Narration. Jakarta: PT Gramedia.

Hackenberg, A. J. (2010). Mathematical Caring Relations İn Action. Journal for Research in Mathematics Education, 236-273.

Hackenberg, A. J. (2010). Students' Reasoning With Reversible Multiplicative Relationships. Cognition and Instruction, 28(4), 383-432.

Howe, R. (1998). The AMS and mathematics education: The revision of the "NCTM standards" Notices of the AMS, 45(2), 243-247. 
Hudoyo, H. (1988). Teaching Learning Mathematics. Jakarta: LPTK Ministry of Education and Culture.

Kabael, Tangul \& Akin, Ayca (2016). Between Pre-Service Mathematics Teachers' Quantitative Reasoning And Their Support For Quantitative Reasoning. 13th International Congress on Mathematical Education Hamburg, 24-31 July 2016.

Karim, N. (2007). Quantitative Reasoning Applications and Modelling in The Real World at Zayed University.

Madison, B. L. (2003). The Many Faces of Quantitative Literacy. Quantitative Literacy: Why numeracy matters for schools and colleges, 3-6.

Malhotra, N.K. \& Birks, D.F. (2007). Marketing Research: An Research, $3^{\text {rd }}$ European Edition, Harlow. UK: Pearson Education.

Mathematical Association of America. (2003). Guidelines for Programs and Departments in Undergraduate Mathematical Sciences. Washinton, DC: Author.

Ministry of Education and Culture. (2006). Minister of National Education Regulation Number 22 of 2006 concerning Content Standards for Primary and Secondary Education Units. Jakarta: BSNP.

Moore, K. C. (2014). Quantitative reasoning and the sine function: The case of Zac. Journal for Research in Mathematics Education, 45(1), 102-138.

Nani K. L., \& Kusumah Y. S. (2015). Efectiveness Ofict-Assisted Project- Based Learning In Enhancing Students' Statistical Communication Ability. International Journal of Education and Research. Vol. 3, No. 8, 187-196.

NCTM. (2000). Principles and Standards for School Mathematics. Virginia: NCTM

Ramful, A., \& Ho, S. Y. (2015). Quantitative Reasoning İn Problem Solving. Australian Primary Mathematics Classroom, 20(1), 15.

Slavin, R. E. (2006). Educational Psychology: Theory and practic (8th Edition). USA: Allyn Bacon.

Sroyer, A. (2013). Quantitative Reasoning in Solving Mathematical Problems. In Proceedings of the National Mathematics and Mathematics Education Seminar. UNY.

Sumarmo, U. (1987). Students 'Mathematical Understanding and Reasoning Abilities are associated with Students' Logical Reasoning Abilities and Some Elements of the Teaching and Learning Process. Dissertation on PPs UPI Bandung.

Sumarmo, U. (2013). Mathematical Thinking and Disposition and Learning: Collection of Papers. Department of Mathematics Education, UPI, Bandung. 
Thompson, P. W. (1993). Quantitative Reasoning, Complexity, and Additive Structures. Educational Studies İn Mathematics, 25(3), 165-208.

Urbina, S. (2004). Essentials of Psychological Testing. New Jersey: John Wiley \& Sons.

Weber, E., Ellis, A., Kulow, T., \& Ozgur, Z. (2014). Six principles for quantitative reasoning and modeling. Mathematics Teacher, 108(1), 24-30. 